Tanja Žigon in Boštjan Udovič

\title{
"Cerkev mora ostati ljudem blizu ne glede na čase«: prvi val koronavirusa (COVID-19) in versko življenje v Sloveniji - analiza primera1
}

"The Church Must Remain Close to the People Regardless of the Times": The First Wave of Coronavirus (COVID-19) and the Religious Life in Slovenia - a Case Study

Povzetek: Članek analizira sprejemanje ukrepov za zaščito vernikov na Slovenskem med COVID-19. Avtorja uvodoma analizirata okvir odločanja o sprejemanju ukrepov COVID-19 na ravni Svetega sedeža in Cerkve na Slovenskem, nato pa nekatere predpostavke preverita z anketo med pevci enega elitnejših pevskih zborov iz Ljubljane. Izsledki ankete kažejo, da so med zaprtjem cerkva na Slovenskem respondenti obrede/bogoslužja spremljali predvsem prek nacionalne televizije, da so v veliki meri spremljali bogoslužje velikega četrtka in velike noči, manj pa velikega petka in sobote, in da so najbolj pogrešali ,občestvo' in ,občestvenost'. Čeprav ima raziskava svoje metodološke omejitve in ukrepi za zaščito pred COVID-19 še niso sproščeni, so ta spoznanja izhodišče za refleksijo in razmislek o delovanju Cerkve na Slovenskem.

Ključne besede: COVID-19, Slovenska škofovska konferenca, občestvo, cerkev, petje

Abstract: The article analyses the measures taken to protect worshipers in Slovenia during the COVID-19 lockdown. The authors first analyse the measures taken concerning the COVID-19 on the level of the Holy See and the Catholic Church in Slovenia, then verify selected hypotheses with the use of answers, obtained by survey among singers in the elite choir in Ljubljana. The answers obtained by respondents show that while the churches were closed, worshipers followed the services/rites mainly on the national TV channel; they largely followed the services on Maundy Thursday and Easter, but less so on Holy Friday and Saturday; worshipers also reported that they mostly missed the ,commu-

1 Prispevek je nastal v sklopu raziskovalnih programov "Slovenija in njeni akterji v mednarodnih odnosih in evropskih integracijah“, št. P5-0177, in „Medkulturne literarnovedne študije“, št. P6-0265, ki ju sofinancira Javna agencija za raziskovalno dejavnost Republike Slovenije. 
nity' and ,communion'. Although the investigation has some methodological limitations and the COVID-19 measures have not yet been called off, the present findings are a starting point to reflect on the functioning of the Church in Slovenia.

Key words: COVID-19, Slovenian Bishops Conference, communion, churches, singing

\section{Uvod in oris raziskovalne problematike}

Letos zgodaj spomladi je ves svet zajel koronavirus z oznako COVID-19. Izbruhnil je konec leta 2019 na Kitajskem in se počasi širil po Aziji, nihče pa ni predvideval, da bo s takšno močjo udaril prav v razvitem svetu. Tudi če ob pripravi tega članka še ni jasno, kako se bo to obdobje končalo in kakšne bodo družbenopolitične in družbenoekonomske posledice epidemije, pa je lahko že zdaj ugotovimo, da so se $v$ tem času zgodile številne spremembe, ki bodo pustile sledi in zaznamovale tudi razvoj v prihodnje. Ena takšnih sprememb, ki smo jih zabeležili med izbruhom virusa, sta bila zaprtje cerkva in prenos bogoslužij/obredov na e-medije (televizija, radio, internet). Slišati je bilo kar nekaj komentarjev, da česa podobnega ne pomnimo. Morda bi bilo točneje navesti, da se to $v$ sodobni zgodovini zaradi izbruha bolezni še ni zgodilo, vendar pa se je zaprtje cerkva v preteklosti že dogajalo. Tako je papež Aleksander VII. leta 1656 ob izbruhu kuge v Rimu ukazal opustitev in zaustavitev vseh bogoslužnih aktivnosti in zaprtje vseh cerkva (VaticanNews 2020), torej »niso bili ukinjeni samo civilni, ampak tudi cerkveni dogodki. Zaprte so bile papeške kapele in verske kongregacije, ukinjene običajne procesije in praznovanja $v$ cerkvenih uradih. In to $v$ dneh, ki so bili za njih še posebej praznični ter privlačni za ljudstvo. ${ }^{2}$ Med sedemletno oziroma tretjo šlezijsko vojno (1756-1763) so cerkve spreminjali v lazarete (Völker 2011), podobno med tridesetletno vojno (Freytag 2003; Kočevar in Preinfalk 2018), zapirali pa so jih tudi med špansko gripo, ki je po Evropi razsajala po koncu prve svetovne vojne (Žužek 2020; Keber 2018; Zupanič Slavec 2019). Eden od načinov boja proti širjenju gripe je bila namreč prepoved množičnih zbiranj oziroma množičnih dogodkov. V sklopu te prepovedi pa so se začasno zapirale tudi cerkve; pri tem zgodovinar Aleš Maver poudarja: vsaj za ZDA je mogoče trditi, da je bil to bolj pritisk civilnih oblasti (Žužek 2020).

$\checkmark$ zgodovini bi nedvomno našli še več podobnih situacij, vendar pa poznamo tudi številna pričevanja, da se je prav med epidemijami povečalo obiskovanje bogoslužij in obredov, saj so verniki verjeli, da lahko bolezensko nadlogo premagajo z molitvijo. Še več, v priprošnjo in pozneje zahvalo Bogu, Mariji ali posameznim svetnikom so celo gradili cerkve. Tako smo tudi v aktualni zdravstveni krizi slišali

2 Izvirni navedek se glasi: „Né solamente furon dismesse le comunanze /.../ civili, ma non meno le sacre, cioè le pontificie cappelle, le consuete processioni, le pie congreghe, la solennità degli uffizii nelle chiese, chiudendole in que' giorni ch'eran per loro segnalatamente festivi, e però attrattivi di molto popolo. (VaticanNews 2020) 
ta ali oni kritični glas, ki je menil, da med krizo cerkva ne bi smeli zapirati, temveč bi morale ostati odprte. Predsednik fundacije Lepanto, Roberto De Mattei, ${ }^{3}$ je v intervjuju za spletni časopis ilGiornale.it (Boezi-Gio 2020) na vprašanje, ali se strinja z zaprtjem cerkva zaradi koronavirusa, povedal:

»Ne. Ne strinjam se. Koronavirus nas potiska v krizno situacijo. Ampak v takih situacijah je vloga duhovnikov enaka vlogi zdravnikov. Da pojasnim: duhovniki morajo na polju duhovnega narediti tisto, kar počnejo zdravniki na zdravstveni ravni. Duhovniki zdravijo duše, zdravniki pa telesa. /.../ Tako kot morajo biti odprte bolnišnice, morajo biti odprte tudi cerkve.»

Tudi papež Frančišek se je na popolno zaprtje cerkva v Rimu odzval z implicitno kritiko, ${ }^{4}$ resda šele potem, ko je vikar za Rim, Angelo De Donatis, že spremenil svojo odločitev in je Dekret št. 468/20, ${ }^{5}$ ki je predvidel popolno zaprtje cerkva, ,relativiziral' z besedami (Diocesi di Roma 2020b):

»Vernike spodbujamo, da se kot odgovorni in zreli posamezniki, do petka, 3. aprila, držijo navodil Sveta ministrov iz zadnjih dni, predvsem uredbe \#ostajamdoma. Sledeč zgoraj napisanemu so verniki oproščeni udeležbe pri praznikih (skladno s kan. 1246-1248 ZCP). Skladno s kan. 1214 ZCP ostajajo zaprte nežupnijske cerkve in druge stavbe, v katerih se lahko izvaja bogočastje. Odprte pa ostajajo župnijske cerkve.«

Navedeno jasno pokaže, da se v okviru poskusa zmanjševanja širitve koronavirusa v Cerkvi do sredine marca 2020 ni oblikovala enotna praksa. Ko se je stanje zaostrilo in se je izkazalo, da se zdravstvena situacija ne bo hitro stabilizirala in bo zaprtje cerkva daljše, je Sveti sedež izdal nekaj navodil, katerih namen je bil, poenotiti prakse/odzive različnih lokalnih Cerkva na aktualno koronakrizo.

Prvi dokument je bil dekret Apostolske penitenciarije ${ }^{6} z$ naslovom Dekret Apostolske penitenciarije glede posebnih odpustkov vernim v času pandemije, podpisan dne 19. marca 2020 (Penitenzieria Apostolica 2020). V dekretu je bilo določeno, komu se lahko podeli popolni odpustek, in do bolnim zaradi koronavirusa, zdravstvenim delavcem, njihovim družinam in vsem tistim, ki - tudi z molitvijo skrbijo za prej omenjene, in kakšni so pogoji za njegov prejem, med drugim spremljanje svete maše prek e-medijev, molitev rožnega venca itd. Popolni odpustek so lahko med pandemijo dobili tudi tisti, ki so vsaj pol ure molili pred Najsvetejšim,

3 Roberto De Mattei je profesor zgodovine, ki sam sebe razume kot tradicionalista (v katoliškem svetu), to pa pomeni, da nasprotuje progresivni in ekumenski liniji znotraj katoliške Cerkve.

4 V nagovoru pri maši v Hiši sv. Marte je papež dejal: „Drastični ukrepi niso vedno najboljši. Zato molimo, da Sveti duh da pastirjem sposobnosti in modrosti, da bodo lahko sprejemali ukrepe, ki božjega ljudstva ne bodo pustili samega." (RaiNews. 2020)

5 Papeški vikar za Rim, Angelo De Donatis, je dne 8. marca izdal Dekret št. 446/20. V prvi točki piše: "Do petka, 3. aprila 2020, ostajajo cerkve v Rimu odprte za osebno molitev. « Nekaj dni pozneje je svojo odločitev z Dekretom št. 468/20 spremenil in se je glasila: „Do petka, 3. aprila 2020, so cerkve v rimski škofiji za vernike zaprte. Odprte ostajajo le kapele, skladno s kan. 1223.« (Diocesi di Roma 2020a; 2020b)

6 To je sodišče, ki ima med drugim pooblastila za podeljevanje pravice do odpustkov. 
brali svete spise, molili rožni venec ali križev pot itd. ${ }^{7}$ (prim. tudi Slovenska katoliška Cerkev 2014). Hkrati z Apostolsko penitenciarijo je tudi Kongregacija za bogoslužje in disciplino zakramentov (Congregatio de cultu divino et disciplina sacramentorum 2020a) izdala Dekret št. 153/20 (Decreto: In tempo di COVID-19), s katerim je de facto zaprla cerkve in dala škofom navodila in pojasnila za obeleževanje velikonočnih praznikov:

"1 - Praznovanje velike noči ni prenosljivo (praznujemo ga na dan, ki je določen v cerkvenem koledarju);

2 - Škofje smejo glede na situacijo v svoji državi krizmeno mašo prestaviti na poznejši datum.

3 - Velikonočno tridnevje: $v$ državah, kjer so civilne in cerkvene oblasti določile omejitve (združevanja idr., op. av.), naj se velikonočno tridnevje izvede na naslednji način:

- Škofje po uskladitvi z nacionalno škofovsko konferenco pripravijo navodila, kako $v$ velikonočnem tridnevju obhajati bogoslužje $v$ stolnicah in župnijskih cerkvah brez fizične prisotnosti vernikov. Vernike se obvesti o začetku bogoslužij. Vsa bogoslužja potekajo v neposrednem prenosu (preko e-medijev), ne pa preko posnetkov.

- /.../ Na veliki četrtek smejo duhovniki obhajati bogoslužje brez prisotnosti vernikov.

- /.../ Na veliki petek se obhaja obred Gospodovega trpljenja.

- /.../ Na veliko soboto vigilija poteka v krajši obliki (opusti se prižig ognja, prižge se samo sveča, opusti se procesija, izvede se Hvalnica velikonočni sveči. Sledi besedno bogoslužje, obnovijo se krstne obljube in izvede se evharistično bogoslužje.

- Ljudske pobožnosti in procesije, ki obogatijo veliki teden in velikonočno tridnevje, se na podlagi presoje škofov lahko opravijo $v$ drugem času, npr. 14. in 15 . septembra. $\ll^{8}$

Šest dni zatem so prvi dekret dopolnili z drugim (Decreto: In tempo di COVID-19 (II), št. 154/20), v katerem so poudarili, »naj duhovniki bogoslužja/obrede velikega tedna zaradi hitre širitve COVID-19 opravljajo brez prisotnosti vernikov, prav tako naj se izogibajo somaševanju, opustijo pa naj tudi ,pozdrav miru' " (Congregatio de cultu divino et disciplina sacramentorum 2020b). Temu so sledila konkretna navodila, in to delno prenovljena in delno dopolnjena navodila za praznike:

"1 - Oljčna/cvetna nedelja: spominjanje Gospodovega vstopa v Jeruzalem naj se izvede znotraj cerkve.

2 - Krizmena maša: glede na različne situacije $v$ državah naj škofovske kon-

7 Popolni odpustek je bilo mogoče dobiti tudi s spremljanjem evharističnega blagoslova Urbi et Orbi papeža Frančiška dne 27. marca 2020.

8 To je v sklopu praznika povišanja sv. Križa in praznika Žalostne Matere božje. 
ference določijo njeno morebitno obhajanje na drug datum.

3 - Veliki petek: pri čaščenju križa naj križ poljubi samo glavni mašnik.

4 - Velikonočna vigilija naj se izvede samo v cerkvah (ne zunaj).»

Pristojna kongregacija je sprejela še dva dekreta. Dekretu št. 155/20 so dodali posebno molitev za čas pandemije (Congregatio de cultu divino et disciplina sacramentorum 2020c), Dekret št. 156/20 pa je omogočil uporabo posebnih mašnih delov/obrazcev za ves čas pandemije, izvzeti so bili le mašni obrazci iz adventa, posta ali velike noči (Congregatio de cultu divino et disciplina sacramentorum 2020d). Nadalje sta bili zaradi COVID-19 sprejeti še dve spremembi: nabirka za Sveto deželo (lat. Colletta pro Terra Sancta), ki jo imamo navadno na veliki petek, se je premaknila na nedeljo, 13. septembra (Congregazione per le Chiese Orientali 2020), prav tako pa je bila prestavljena tudi nabirka Petrov novčič (it. L'Obolo di San Pietro), z 29. junija na 4. oktober (Direttore della Sala Stampa della Santa Sede 2020).

Ta kratki oris ukrepov, ki jih je sprejel Sveti sedež, kaže, da se je Cerkev relativno hitro odzvala na nevarnosti razširjanja virusa. Z določitvijo dokaj rigoroznih ukrepov, ki so jim nekateri celo aktivno in javno nasprotovali, je skušala določiti okvire, znotraj katerih so potem ukrepe sprejemale lokalne Cerkve, to pa pomeni, da je Sveti sedež s svojimi ukrepi omogočil oziroma celo dal napotilo lokalnim škofovskim konferencam, da so sprejele nekatere ukrepe, ki so pomagali k zajezitvi COVID-19.

\section{Reakcija slovenskih cerkvenih oblasti: hitro in učinkovito}

Slovenija je prve bolnike s COVID-19 zabeležila šele v začetku marca 2020. Kakor je razvidno iz prikaza (slika 1) spodaj, je bilo bolnikov v prvem tednu relativno malo, po 10. marcu 2020 pa so se začele kumulativne številke strmo vzpenjati.

Na presečni datum, 12. marca 2020, ko je Slovenska škofovska konferenca (SŠK) sprejela ukrepe za preprečevanje širitve COVID-19, je bilo v Sloveniji 96 okuženih bolnikov in še nič mrtvih. Skok v tednu dni z enega okuženega na 96 okuženih, izjemno zahtevna situacija v Italiji (UTILS 20202) in strogi ukrepi, ki jih je sprejela Vlada Republike Slovenije, so zagotovo vplivali na SŠK, da se je na situacijo v državi odzvala hitro in učinkovito (prim. Globokar 2020, 379-394). ${ }^{9}$

Dne 12. marca 2020 je SŠK izdala Izredna navodila slovenskih škofov za preprečevanje širjenja koronavirusa COVID-19: odpoved svetih maš do preklica ${ }^{10}$ (SŠK

\footnotetext{
9 O okvirih delovanja, o odnosu med državo in Cerkvijo in o drugih, s tem povezanih vprašanjih prim. Naglič (2013, 85-96); Bahovec (2015, 335-346); Mihelič (2015, 129-142); Svetlič (2016, 37-49) in Kraner (2018, 611-624).

$10 \quad \mathrm{~V}$ nadaljevanju: Navodila.
} 


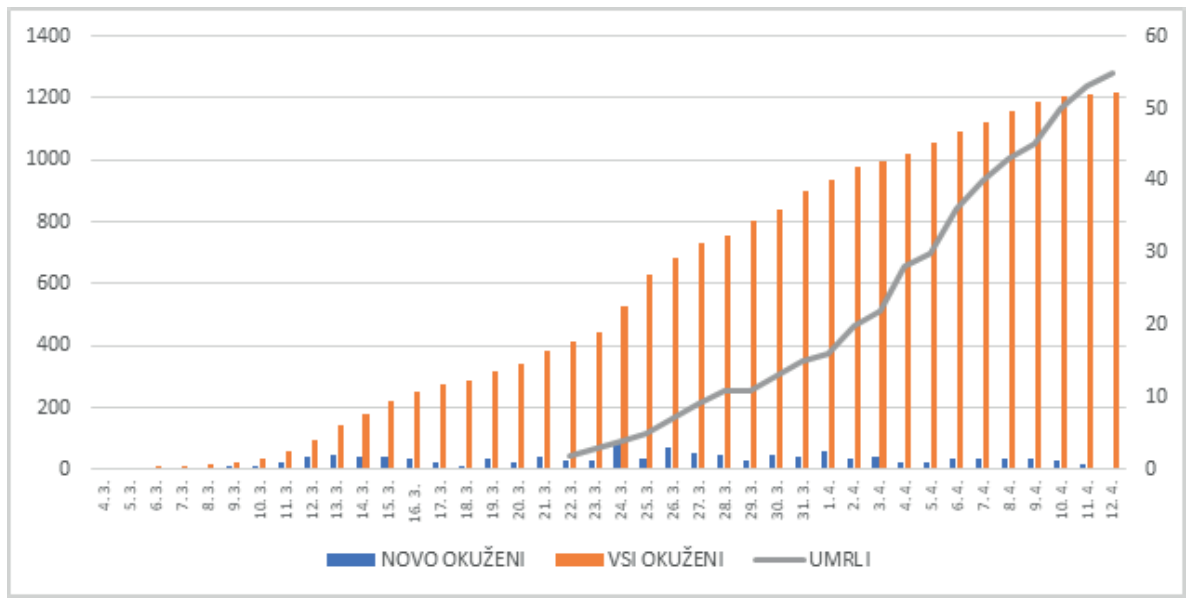

Graf 1: Število bolnikov s COVID-19 in število umrlih. Vir: Pripravljeno na podlagi STA (2020).

2020a; več tudi v Slatinek, 2020, 403-413), ki so stopila v veljavo v petek, 13. marca, ob polnoči. $V$ Navodilih so slovenski škofje $v 17$ točkah določili pogoje za delovanje Cerkve na Slovenskem med COVID-19. Glavna (in prva točka) navodil se je glasila: „Do nadaljnjega so odpovedane vse svete maše, podeljevanje zakramentov, zakramentalov, ljudske pobožnosti, župnijska praznovanja in drugi dogodki ter vsa srečanja." V neformalnih pogovorih z nekaterimi duhovniki smo ugotovili, da so se sami večinoma strinjali s to določbo, nekateri so bili skeptični, češ da so škofje podlegli družbeni paniki, nekateri pa so bili celo bolj ostri in so vztrajali, da bi morale cerkve prav v teh težkih časih ostati odprte, saj so duhovniki tisti, ki lahko ublažijo duhovne težave vernikov. Ne glede na te razlike so vsi duhovniki, s katerimi smo se neformalno pogovarjali, dejali, da se svojemu mnenju ne bodo odpovedali, da pa bodo navodila SŠK spoštovali. Glede na neformalne informacije, ki smo jih dobili v osebnih pogovorih, smo želeli preveriti tudi, ali je SŠK dobila kakršnokoli pritožbo na sprejetje Navodil. Iz Tiskovnega urada SŠK smo dobili odgovor, da »niso seznanjeni z omenjenim nezadovoljstvom«, in dodali so, da so dobili »več pisem duhovnikov in vernikov z zahvalami in pohvalami za jasna navodila in ukrepe ter za nadaljnje spremljanje njihovih vprašanj in odgovarjanje nanje« (Kraner 2020b). Skratka, uradni podatki kažejo, da so slovenski duhovniki Navodila SŠK v polnosti spoštovali.

Poleg ,zaprtja cerkva'11 je SŠK (2020a) sprejela tudi druge ukrepe za zajezitev COVID-19:

11 V 6. točki Navodil je bilo glede cerkva določeno: »Kjer je to mogoče, so lahko cerkve med epidemije odprte izključno pod naslednjimi pogoji: a) cerkve so odprte samo za osebno molitev zdravih vernikov brez simptomov akutne pljučne bolezni; b) istočasno je lahko v cerkvi največ 10 oseb, med katerimi mora biti vsaj 1,5 metra razdalje; c) cerkev, ki je odprta za vernike, je treba vsaj dvakrat na dan očistiti z razkužilnimi sredstvi (kljuke vrat, klopi itd.); č) vernikom mora biti v cerkvi na voljo razkužilno sredstvo za roke. « Navodila so bila tolmačena in sensu stricto, to pa je de facto pomenilo, da je bilo laže kakor slediti tem navodilo cerkve zapreti. 
ukinitev ali preložitev obredov, zakramentov, zakramentalov, med drugim prepoved somaševanja duhovnikov, ukinitev vseh bogoslužij, obredov in pobožnosti na prostem, odlog spovedi, opravljanje cerkvenih pogrebov le v ožjem družinskem krogu in brez pogrebne maše, podelitev bolniškega maziljenja ob zaščiti duhovnika in bolnika, preložitev porok in krstov, izpraznitev kropilnikov z blagoslovljeno vodo,

- preklic/preložitev verouka,

- zaprtje cerkvenih uradov: župnijskih pisarn, cerkvenih arhivov, cerkvenih uradov na splošno,

- zaprtje cerkvenih šol in vrtcev,

- omejitev stikov v samostanih z zunanjimi obiskovalci.

Škofje so določili, da slovenskim katoličanom podelijo spregled dolžnosti udeležbe pri nedeljski sveti maši. Kakor so zapisali, naj "verniki nadomestijo odsotnost od svetega bogoslužja z molitvijo, postom, dobrimi deli, prebiranjem Božje besede, spremljanjem svete maše po radiu, TV oziroma spletu ter s prejemom duhovnega obhajila «. ${ }^{12}$

Ker je SŠK Navodila sprejela pred določitvijo inštrukcij Svetega sedeža, smo SŠK vprašali, na kateri pravni podlagi so slovenski škofje Navodila sprejeli. V zvezi s tem nam je dr. David Kraner odgovoril, da »mora vsaka škofovska konferenca v določenih izrednih primerih upoštevati navodila svoje države«. Kar zadeva pravne podlage za sprejetje ukrepov, pa nam je bilo sporočeno, da pooblastila škofovskih konferenc lahko najdemo v kan. 455 (§1-2) Zakonika cerkvenega prava, pa tudi v Direktoriju za pastoralno službo škofov, Apostolorum successores, in to v členih 31 in 64 (Kraner 2020a), ki daje škofovskim konferencam in škofom pravico pri sprejemanju pravnih aktov na področju njihove škofije. V tem kontekstu škofje in škofovske konference lahko sprejemajo kakršnekoli pravno zavezujoče akte in odločitve, če so v skladi z Zakonikom cerkvenega prava. Malce manj jasno je bilo sosledje pri podelitvi spregleda dolžnosti udeležbe pri nedeljski sveti maši. SŠK je o tem odločila pred Svetim sedežem, čeprav - če smo zelo natančni - Sveti sedež o tem ni nikoli odločal. Analogno lahko tolmačimo dekreta št. 153/20 in 154/20 Kongregacije za bogoslužje in disciplino zakramentov (Congregatio de cultu divino et disciplina sacramentorum 2020a in 2020b). Če je bilo torej določeno, da bodo velikonočne slovesnosti $v$,zaprtih cerkvah', potem to velja tudi za navadne nede-

12 Glede duhovnega obhajila je bilo med verujočimi kar nekaj nejasnosti, predvsem glede tega, ali je duhovno obhajilo ekvivalent ,fizičnemu'. Podlaga za to vprašanje izhaja iz kanona 920, ki določa, da mora vsak vernik, ki je že bil pri prvem obhajilu, prejeti obhajilo vsaj enkrat v letu. $V$ §2 je to še bolj konkretizirano z naslednjo navedbo: „To zapoved (gl. prejšnjo poved) mora spolniti v velikonočnem času, razen če jo iz upravičenega razloga spolni v drugem času med letom«. Glede na to, da je bilo nemogoče udejanjiti §2, nas je zanimalo, ali obstaja pravna podlaga za podelitev duhovnega obhajila. Kraner (2020b) je na to naše vprašanje odgovoril tako: „Ne glede na dejstvo, ali se v cerkvah opravlja javna liturgija ali ne, lahko duhovno obhajilo, ki velja tako za mlade kakor za starejše ali bolnike, prejmemo, ko ne moremo k svetemu obhajilu zaradi svojega zdravstvenega stanja, zaradi stanja greha ali kadar duhovnik ne more do nas oziroma kadar ne moremo ali ne smemo pristopiti k zakramentalnemu obhajilu. /.../ Duhovno obhajilo ne more nadomestiti zakramentalnega (poudarek T. Ž. in B. U.), vendar je naš notranji izraz in iskrena želja, biti v Kristusovi bližini.« 
lje in delavnike. A če smo natančni, je SŠK odločitev sprejela dne 12. 3. 2020, to je: nekaj dni zatem, ko je papeški vikar za Rim ,ukinil' javne maše in dovolil, da so cerkve odprte le za osebno molitev. $V$ tem kontekstu lahko $z$ veliko verjetnostjo sklenemo, da je SŠK svoje odločitve sprejela po zgledu dogajanja v drugih državah in,$v$ dobri veri', predvsem pa v skladu z navodili državnih oblasti. Nanje opozarja tudi Kraner (2020a), ko pravi, da mora »Katoliška cerkev v Sloveniji upoštevati in se ravnati po navodilih medicinske stroke in državne oblasti ter njihovih odlokov", kakor je v svojih navodilih, v Dekretih št. 153/20 in št. 154/20, poudarila tudi Kongregacija za bogoslužje in disciplino zakramentov (Congregatio de cultu divino et disciplina sacramentorum 2020a; 2020b).

Dne 23. aprila 2020 je SŠK sprejela Navodila slovenskih škofov za vzpostavitev javnega bogoslužja v slovenskih cerkvah v času epidemije COVID-19 (2020b), ki so stopila v veljavo dne 4. maja 2020. S temi navodili so dovolili postopno odpiranje cerkva, pod izredno ostrimi (samo)zaščitnimi ukrepi. Navodila imajo 9 točk, s številnimi podtočkami. Hkrati pa je SŠK na spletni strani objavila tudi mnoge odgovore na vprašanja (SŠK 2020c), ki bolj natančno definirajo nekatere postopke in prijeme, predvsem pa pomen (samo)zaščitnih ukrepov. Kar je zanimivo z vidika te analize, pa so naslednje točke:

- vsi verniki nosijo pri bogoslužju zaščitne maske (tč. 1, 1b);

- pri vhodu v cerkev si mora vernik razkužiti roke. Sredstvo za to zagotovi župnik oziroma župnijski sodelavci. Če ga ne morejo (npr. materialne okoliščine), se župnik obrne na lokalno civilno zaščito oziroma škofijskega ekonoma. Če razkužila ni mogoče zagotoviti, maš z udeležbo vernikov ni mogoče obhajati (poudarek T. Ž. in B. U.) (tč. 1, 1c);

- verniki morajo v cerkvi in v klopeh ohranjati medsebojno varnostno razdaljo vsaj 1,5 metra, kar pomeni, da mora biti vsaj vsaka druga vrsta prazna (tč. 1, 1d);

- sodelovanje pevskega zbora med sveto mašo ni dovoljeno zaradi bližine med pevci in možnosti okužbe (tč. 1, 1g);

- posamično podeljevanje zakramenta svetega krsta je dovoljeno ob navzočnosti najožjih sorodnikov oziroma največ 15 oseb, ki med seboj ohranjajo ustrezno in obredu primerno razdaljo ter nosijo zaščitne maske (tč. 3, 9);

- podeljevanje zakramenta svetega zakona je dovoljeno ob navzočnosti najožjih sorodnikov oziroma največ 15 oseb, ki med seboj ohranjajo ustrezno razdaljo ter nosijo zaščitne maske (tč. 3, 12).

Navodila so izjemno omejujoča, $v$ mnogih primerih morda celo neizvedljiva, kakor priznava tudi SŠK, ko (samo)zaščitno pove: če kje ni mogoče zagotoviti razkužila, potem se pač maša $z$ verniki v tej cerkvi ne izvede. Tudi pri določanju varnostne razdalje (prim. Petkovšek 2020, 293-320) je jasno, da cerkev sprejema vse državne ukrepe in jih spoštuje (prim. Strehovec 2020, 395-401). Še najbolj ,problematični' oziroma v realnem življenju neizvedljivi sta navodili obhajanja krsta in poroke. Vemo namreč, da je to za družino ali par lahko izjemno svečan dogodek, zato je določitev nošenja maske resna ovira ( $v$ spomin krsta ali poroke bi bili starši, botri, mladoporočenci v maskah na sliki za vedno) temu, da se bodo do preklica teh navodil krsti in poroke sploh izvajali. Če so krsti načeloma relativno 
premakljivi, ${ }^{13}$ so poroke ,teže' premakljive. Z določilom o obveznem nošenju mask je torej SŠK implicitno odprla pot do izvedbe samo civilnih porok brez cerkvenega obreda, a o tem je sedaj še prezgodaj razpravljati, saj bodo več pokazale prihodnje analize. ${ }^{14}$

\section{Empirična analiza ukrepov SŠK}

Predstavljena normativna analiza ukrepov je izhodišče za uokvirjanje odločevalskega procesa o COVID19 v okviru slovenskih škofij, vendar pa sliko dejanskega stanja lahko dobimo le, če raziščemo tudi odziv tistih, katere so ukrepi, ki jih je sprejemala SŠK, najbolj zadevali, to je: vernikov.

\subsection{Metodologija analize}

Da bi preverili odziv vernikov, smo se odločili znotraj skupine vernikov, članov enega elitnejših cerkvenih pevskih zborov na Slovenskem, izvesti anketo o tem, kako so razumeli ukrepe SŠK, kako so jih sprejeli, in končno, kakšna so bila ob tem njihova občutja. Postavili smo tri teze, ki smo jih želeli preveriti:

T1: Verniki so večinoma podpirali ukrepe, ki jih je sprejela SŠK.

T2: Verniki so odsotnost obredov/bogoslužij v veliki meri nadomeščali s spremljanjem obredov/bogoslužij po e-medijih.

T1a: Verniki so pogosteje spremljali bogoslužja papeža Frančiška kakor »slovenska« bogoslužja.

T1b: Verniki so bogoslužja spremljali predvsem prek Radia Ognjišče in programa ARS.

T3: Verniki so še najbolj pogrešali bogoslužno glasbo (razlog: ker so sami pevci), šele nato vse drugo.

Anketa je bila izvedena na spletu, s programom $1 \mathrm{ka}$, in to med 19. in 26. aprilom 2020, torej dober mesec po uvedbi ukrepov in po sklepu velikonočnih praznikov, a še pod vtisom drugačnega praznovanja. Število respondentov, ki bi lahko na anketo odgovorilo, je bilo 63 (evidenca članov analiziranega pevskega zbora), od tega 45 žensk in 18 moških. Na anketo je odgovorilo 37 vprašanih (59\%), od tega 12 moških (67 \%) in 25 žensk (56\%). Starostna struktura respondentov je prikazana v tabeli 1.

13 Kan. 867 (§1) Zakonika cerkvenega prava določa: „Starši so dolžni poskrbeti, da bodo otroci krščeni v prvih tednih (po rojstvu - op. av.)«.

14 Natančno branje Navodil z dne 23. aprila 2020 ne daje odgovora, ali se priprave na krst oziroma poroko izvedejo. Po analogiji z izvajanjem verouka se torej lahko izvedejo po e-medijih, drugače pa so odjavljene. Če torej velja to zadnje, potem nastopi težava, saj Zakonik cerkvenega prava (kan. 851, §2) zahteva pripravo staršev na krst otroka oziroma pripravo parov na poroko (kan. 1063 §2). 


\begin{tabular}{|c|c|c|}
\hline Odgovori & Frekvenca & Veljavni odstotek \\
\hline 1 (do 35 let) & 2 & $5 \%$ \\
\hline 2 (36-55 let) & 15 & $41 \%$ \\
\hline 3 (56 let ali več) & 20 & $54 \%$ \\
\hline Skupaj & 37 & $100 \%$ \\
\hline
\end{tabular}

Tabela 1: Starostna struktura respondentov. Vir: Naš lastni prikaz.

\subsection{Analiza rezultatov}

\subsubsection{Splošno spremljanje obredov}

Pred zaprtjem cerkva je obrede po televiziji redno spremljalo $15 \%$ respondentov, občasno pa $41 \%$ respondentov; po zaprtju cerkva je obrede po e-medijih spremljalo $95 \%$ respondentov, le eden od respondentov obredov ni spremljal. Bogoslužje velika četrtka je spremljalo $66 \%$ respondentov, na veliki petek $78 \%$, na veliko soboto $71 \%$ (k temu moramo prišteti še $8 \%$ respondentov, ki so spremljali blagoslov jedil), medtem ko je bogoslužje velike noči po e-medijih spremljalo 95 $\%$ vseh respondentov. Tu so se pokazale tudi nekatere statistično značilne povezave: respondenti, ki so spremljali obrede/bogoslužja velikega četrtka, so v veliki meri spremljali tudi bogoslužja velike sobote $(r=0,61)$. Druge povezave so resda statistično značilne, a so veliko šibkejše..$^{15}$ To pomeni, da lahko sklenemo le: tisti, ki so spremljali obrede/bogoslužja velikega četrtka, so v veliki meri spremljali tudi obrede/bogoslužja velike sobote. Križne korelacijske analize resda omogočajo potrditev predpostavke, da posamezniki spremljali vsa bogoslužja velikega tedna in velike noči.

Zanimalo nas je tudi, ,čigave' obrede/bogoslužja so respondenti spremljali. Na voljo so imeli tri odgovore: bogoslužja papeža Frančiška, (b) bogoslužja iz slovenskih cerkva in (c) križev pot iz Rima. Respondentom smo omogočili, da so izbrali več odgovorov (tabela 2 ).

\begin{tabular}{|c|c|c|}
\hline & Frekvence & Delež (\%) \\
\hline Bogoslužja papeža Frančiška & 22 & 58 \\
\hline Bogoslužja iz slovenskih cerkva & 35 & 92 \\
\hline Križev pot iz Rima & 18 & 47 \\
\hline
\end{tabular}

Tabela 2: Katere obrede/bogoslužja ste spremljali po e-medijih? Vir: Naš lastni prikaz.

Respondentom smo ponudili tudi možnost ,Drugo' in dobili naslednje odgovore: »bogoslužja iz Škofijske klasične gimnazije«, »obred pri Mariji Vnebovzeti v Clevelandu« in »bogoslužje iz domače župnije«. V skladu s pričakovanji se je po-

15 Obstaja šibka pozitivna korelacija med tistimi, ki so spremljali bogoslužja/obrede velikega četrtka in velikega petka $(r=0,34)$, in med tistimi, ki so spremljali obrede velikega petka in velike sobote $(r=0,36)$. Med spremljanjem bogoslužij svetega tridnevja in velike noči prav tako obstaja šibka pozitivna korelacija (rčetrtek/nedelja =0,35; rpetek/nedelja =0,16; rsobota/nedelja $=0,36$ ). 


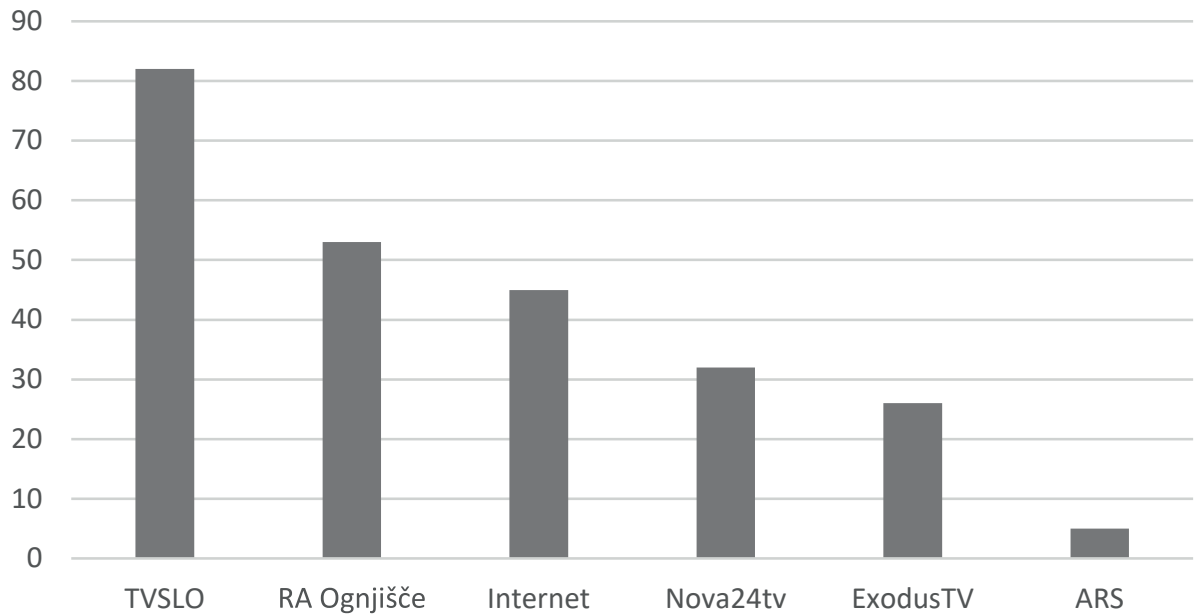

Graf 2: Delež respondentov, ki so obrede/bogos/užja spremljali prek televizijskih zaslonov in radia (v \%, možnih več odgovorov). Vir: Naš lastni prikaz.

kazalo, da so respondenti večinoma spremljali bogoslužja iz slovenskih cerkva. Preseneča pa, da je relativno majhen delež respondentov spremljal križev pot papeža Frančiška iz Rima. ${ }^{16}$

Seveda je bilo logično vprašanje tudi, prek katerega medija so respondenti spremljali bogoslužja. Predvidevali smo, da bo imel prednost radio, a teze nismo potrdili (prim. slika 2).

Zanimiv podatek je dejstvo, da je $45 \%$ respondentov bogoslužja/obrede spremljalo prek interneta. Zato nas je zanimalo, ali obstaja povezava spola respondenta oziroma starostne skupine respondenta s poslušanjem obredov/bogoslužij prek interneta. Pokazala se je povezava, da so mlajši respondenti pogosteje poslušali obrede/bogoslužja prek interneta, medtem ko so najstarejši respondenti obrede večinoma spremljali na kanalu Nova24tv. ${ }^{17}$ Zanimiva ugotovitev je tudi, da glede na spol in medij, prek katerega so respondenti spremljali bogoslužja/obrede, statistično značilnih povezav ni mogoče najti. ${ }^{18}$

\subsubsection{Občutki ob spremljanju obredov/bogoslužij}

Vprašanje, ki smo ga postavili respondentom, je zadevalo tudi občutke in občutja, ki so jih doživljali ob spremljanju obredov/bogoslužij. Pri tem nas je zanimalo, ali

16 Da bi primerjali, ali je bilo to tako le letos, bi morali imeti podatke tudi za prejšnja leta. Tako na podlagi pridobljenih podatkov ne moremo sklepati, ali je to običajno stanje, odklon od običajnega stanja ali celo ,izboljšano' stanje.

17 O starejših vernikih in njihovi duhovni oskrbi prim. Macuh in Raspor (2018, 641-660), Filej in Kaučič (2019, 555-568).

18 Nakazuje se statistično značilna povezava, da so obrede na Exodus TV relativno pogosteje spremljale ženske kakor moški. 
so bili občutki enaki kakor takrat, ko so ta bogoslužja spremljali ,v živo'. 81 \% respondentov je odgovorilo, da so bili ti občutki drugačni, $19 \%$ pa, da so bili enaki. Tistim, ki so odgovorili nikalno, to je: da so bili občutki drugačni, smo vanketi dali možnost, da pojasnijo, zakaj menijo, da so bili občutki drugačni. $V$ tabeli 3 navajamo nekaj skupin odgovorov, ki so jih navedli respondenti.

\begin{tabular}{|c|c|c|c|}
\hline $\begin{array}{l}\text { Odtujenost/ } \\
\text { Oddaljenost }\end{array}$ & $\begin{array}{l}\text { Odsotnost občestva in } \\
\text {,cerkve' (kot prostora) }\end{array}$ & Odsotnost petja & $\begin{array}{c}\text { Odsotnost pristopa k } \\
\text { evharistiji }\end{array}$ \\
\hline 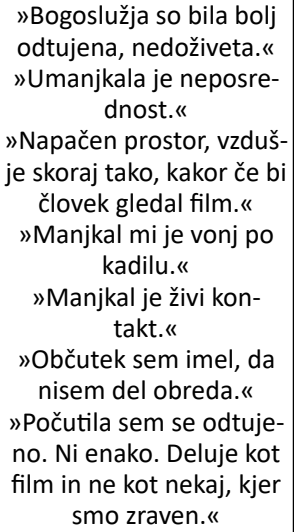 & $\begin{array}{c}\text { „Bogoslužje je bilo } \\
\text { okrnjeno,v bistvu' (obče- } \\
\text { stvenost).« (2x) } \\
\text { „Manjkal mi je občutek } \\
\text { skupnosti in stik z druži- } \\
\text { no." } \\
\text { „V cerkvi se laže umiriš, } \\
\text { laže se je zbrati. Oditi } \\
\text { ven iz vsakdanjih prosto- } \\
\text { rov, v kraj tišine. Kjer se } \\
\text { umiriš in zbereš ter } \\
\text { usmeriš svoje bivanje v } \\
\text { en cilj.» } \\
\text { »Manjkalo mi je doživlja- } \\
\text { nje cerkve (prostora, } \\
\text { vzdušja).« }\end{array}$ & $\begin{array}{c}\text { »Umanjkala je lepota } \\
\text { bogoslužja, ki jo pričara } \\
\text { pevski zbor.» } \\
\text { „Manjkalo mi je petje v } \\
\text { zboru, glasno doneče } \\
\text { orgle.» } \\
\text { „Pogrešam petje.» }\end{array}$ & $\begin{array}{l}\text { „Možnost prejema zgolj } \\
\text { duhovnega obhajila.« } \\
\text { „Pri prenosih ne morem } \\
\text { prejeti zakramenta. } \\
\text { Najbolj pogrešam zakra- } \\
\text { mente.» } \\
\text { „Nisi v živo navzoč. } \\
\text { Prejmeš samo duhovno } \\
\text { obhajilo.» }\end{array}$ \\
\hline
\end{tabular}

Tabela 3: Občutki ob spremljanju bogoslužij/obredov prek e-medijev Vir: Naš lastni izbor.

Nasploh bi lahko dejali, da je bila glavna težava, s katero so se respondenti soočali pri spremljanju bogoslužja prek e-medijev, v tem, da jim je bilo vse skupaj zelo tuje. Niso mogli ponotranjiti sporočilnosti in sporočil. To potrjujejo tudi navedbe kakor: "cerkev je le cerkev« ali pa "preveč brezosebno je bilo vse skupaj«, "če si navzoč v cerkvi, si dejaven, prek medijev si le opazovalec«, "zdelo se mi je, da ni resnično«. Odtujenost od obredov/bogoslužij je tako najbolj zaznamovala občutke tistih, ki so trdili, da so bila bogoslužja zanje drugačna. Pri tem moramo podčrtati tudi pomen občestvenosti, ki so ga respondenti večkrat omenili in ga poudarjata tudi Katekizem katoliške Cerkve $(1993$, čl. 751; 1097; 1383) in Zakonik cerkvenega prava (kan. 840). Dva respondenta sta navedla, da je bila udeležba pri obredih/bogoslužju prek e-medijev boljša: »ker sem bila bolj zbrana in osredotočena na dogajanje; globlje sem lahko doživljala bogoslužje kakor prej v živo« in "drugače je bilo, celo bolje kakor v živo«.

Na koncu ankete smo respondentom omogočili, da so izrazili še druge (pre/po) misleke v zvezi s spremljanjem bogoslužij/obredov prek e-medijev. Nekateri so poudarili, da je bilo zaprtje cerkva lahko razumeti kakor: "merjenje daljav in strani naše vere", eden od respondentov je navedel, da "pogreša skupnost, ljudi, pogovore v živo ter osebni stik z duhovnikom «. Dva respondenta sta izpostavila problem prazne cerkve za duhovnike, ki »morajo v takšni cerkvi maševati«, pa tudi problem mikrofonije, ki se je dogajal med prenosi bogoslužij/obredov. Pomemben 
poudarek v odprtih odgovorih je bil tudi na tako imenovanem družbenem elementu, elementu druženja. Respondenti so tako poudarjali: »upam, da se cerkve spet odprejo, da se srečam s sopevci «, "pogrešam naša druženja «, »osama nam je pokazala vrednost druženja in petja pri mašah«. Med odgovoril pa so nekateri izrazili tudi kritiko cerkvenih oblasti. Nekdo je zapisal: ॥Vsem nam bo dobro delo, še posebej Cerkvi, ki se bo morala soočiti z nekaterimi spremembami sveta. Cerkev mora ostati ljudem blizu ne glede na čase. " Neki drug odgovor pa se je glasil: »Cerkev je bila preveč servilna civilnim oblastem. Cerkva ni bilo treba zapreti. « ${ }^{19}$

\subsubsection{Pomen glasbe pri spremljanju obredov/bogoslužij}

Ker smo pričakovali odgovore, da so bila bogoslužja bolj odtujena, kakor če bi v njih sodelovali ,v živo', smo predvidevali, da so si skušali respondenti bogoslužja ,olepšati'. Izhajajoč iz dejstva, da smo anketo izvedli med člani pevskega zbora, smo predpostavljali, da so ob prenosu bogoslužij/obredov tudi sami peli. Zato smo najprej preverili, ali naša teza o tem drži. 70 \% respondentov je pritrdilo naši tezi, $30 \%$ pa jih ob prenosu bogoslužij ni pelo. Tistim, ki so ob prenosu bogoslužij/ obredov peli, smo ponudili tri trditve (možen je bil odgovor na vse tri), s katerimi bo pojasnili, zakaj so ob prenosu bogoslužja/obredov zraven peli tudi sami. Odgovore prikazuje tabela 4.

\begin{tabular}{|c|c|c|}
\hline & Povprečje & Mediana \\
\hline ... sem s petjem obrede bolj doživel(-a) $(\mathrm{N}=23)$ & $4,26(\sigma=1,137)$ & 5 \\
\hline ... sem si obrede s tem olepšal(-a) $(\mathrm{N}=22)$ & $3,86(\sigma=1,246)$ & 4 \\
\hline .. sem tako čutil(-a) $(\mathrm{N}=22)$ & $4,41(\sigma=1,221)$ & 5 \\
\hline
\end{tabular}

Tabela 4: Ob prenosu bogoslužij sem pel, ker ... (1 = s trditvijo se popolnoma ne strinjam; 5 = s trditvijo se popolnoma strinjam) Vir: Naš lastni izračun.

Čeprav velikih razlik ni, pa lahko vidimo, da so respondenti ob prenosu bogoslužij peli bolj zato, ker so tako čutili oziroma so s tem obrede bolj doživeli, kakor zato, da bi peli, ker bi si želeli obrede olepšati. Analiza grafične in frekvenčne razporeditve pokaže, da je petje ob prenosu izviralo bolj iz trenutnega občutja kakor iz doživetja. Tega ne smemo zanemariti sploh v kontekstu, da imajo tudi obredi/ bogoslužja pomemben vpliv na čustva in občutja posameznikov. Petje ob prenosih bogoslužij je tako posamezniku dalo (imaginarni) občutek, da je del obreda. Posameznik je na takšen način (verjetno podzavestno) želel predvsem zmanjšati občutek odtujenosti obreda/bogoslužja zaradi njegovega e-prenosa. Tudi tu nas je zanimalo, ali spol in starost vplivata na rezultate, a izračuni so pokazali, da med spolom oziroma starostjo in petjem ob prenosu obredov ni statistične povezave.

19 Ob zadnjem zgledu sta dva odgovora združena. Poleg kritik pa so se med odgovori našle tudi pohvalne besede; tako je nekdo cerkvene oblasti pohvalil: „Popolnoma se strinjam s tem, da morajo biti v tej situaciji cerkve zaprte. /.../ Pohvaliti moram vse prenose, vse obrede po medijih, vsi so se potrudili po svojih najboljših močeh v tej težki situaciji. Ker ne morem v cerkev, mi tudi prenosi veliko pomenijo. Ne morejo pa nadomestiti maše sv živor. Vsem ki so pripravili in omogočili prenose, se iskreno zahvaljujem." 
Ker smo anketirali cerkveni pevski zbor, smo želeli ugotoviti še, v kolikšni meri je pogrešanje obredov/bogoslužij ,v živo' povezano s pevskimi vajami, s petjem pri bogoslužjih in z druženjem s sopevci. Analiza je pokazala, da statistično značilnih povezav med temi spremenljivkami ni mogoče najti.

Končno nas je zanimalo nas še, ali obstaja kakršnakoli povezava med spolom in pogrešanjem pevskih vaj oziroma med starostjo in pogrešanjem pevskih vaj. Statistična analiza je potrdila, da ženske pogrešajo ,druženja na pevskih vajah', prav tako se pri njih nakazuje statistična povezava s spremenljivko ,pogrešam pevske vaje', medtem ko pri moških te povezave ne moremo najti. ${ }^{20}$

\section{Razprava in sklep}

Namen članka je bil prikazati okvir in značilnosti sprejemanja ukrepov Cerkve na Slovenskem med izbruhom COVID-19. V analizi smo prišli do pet temeljnih ugotovitev.

Prvič, pokazalo se je, da je Cerkev na Slovenskem na nastop COVID-19 reagirala skorajda takoj po izbruhu bolezni na Slovenskem in tudi pred uradnimi smernicami, ki jih je določil Sveti sedež. To lahko pripišemo predvsem temu, da je SŠK spremljala ukrepe, ki so jih sprejemale sosednje države, in nanje prav tako zelo hitro reagirala, morda (po mnenju nekaterih sogovornikov in anketirancev) tudi prestrogo. $V$ tem oziru je zgovoren odgovor SŠK na vprašanje, na kateri podlagi je SŠK sprejela ukrepe z dne 12. marca 2020, iz katerih izhaja, da mora cerkvena oblast slediti navodilom državnih oblasti. Ta(-kšen) odgovor bi lahko razumeli v duhu razprave Zdenka Roterja $(1996,80)$, ki poudarja, da bi na Slovenskem 7. člen Ustave Republike Slovenije razumeli kot »pozitivno ločitev med verskimi skupnosti in državo« (fr. laïcité libérale), ki »omogoča dogovorno sodelovanje in sporazumevanje, ko gre za skupno in soglasno dognane stvari v korist splošne blaginje« (Udovič 2020; prim tudi Valentan 2020, 609-622).

Druga ugotovitev zadeva na rezultate ankete; govorimo o pomenu, ki so ga za respondente imeli e-mediji med zdravstveno krizo COVID-19. Kakor kažejo rezultati, je nacionalni RTV servis zelo dobro opravil svojo nalogo nosilca obveščanja in posrednika drugih vsebin, $v$ našem primeru prenosa bogoslužij/obredov med krizo COVID-19. Več kakor 80 \% respondentov je bogoslužja/obrede namreč spremljalo prav prek nacionalne televizije, Radio Ognjišče je na drugem mestu in zaostaja za 30 odstotnih točk. Podatek je zanimiv ne le zato, ker se v njem zrcali izjemen pomen javnega TV servisa za verujoče oziroma med krizo, temveč tudi zato, ker je imela TV prednost pred radiem. To pa pomeni, da so si verniki vzeli čas za spremljanje bogoslužja/obredov in jih niso jemali kot nekaj, kar lahko poslušaš mimogrede, kakor lahko, na primer, med poslušanjem radia opravljaš še mnogo drugih stvari. TV je v tem oziru drugačen medij. Rezultati analize nadalje tudi pokažejo, da verniki obrede/bogoslužja vse pogosteje spremljajo prek interneta (tudi

20 Tveganje je previsoko, da bi to lahko z zanesljivostjo trdili. 
prek družabnih omrežij), to pa pomeni, da bo morala SŠK več pozornosti posvetiti tudi temu področju.

Tretja ugotovitev, ki je izjemno pomembna, je, da so verniki/respondenti v veliki meri podpirali in razumeli ukrepe SŠK. To mnenje resda ni bilo soglasno, a z veliko zanesljivostjo lahko trdimo, da so bili ukrepi SŠK za preventivo pred COVID-19 sprejeti pozitivno.

Četrta ugotovitev je povezana s spremljanjem bogoslužij. Verniki so spremljali predvsem maše/obrede velikega četrtka in velike noči, velikega petka in sobote pa malce manj. Najmanj so spremljali obrede velikega petka. Kar je še posebej presenetljivo, je to, da je manj kakor 50 \% respondentov spremljalo križev pot iz Rima. Zakaj je to tako, bo morala odgovoriti druga raziskava. Samo ugibamo lahko, ali je temu morda botrovalo dejstvo, da križev pot tokrat ni potekal v Koloseju, temveč na trgu sv. Petra, po drugi strani pa je mogoče, da vernikov prenos križevega pota iz Rima, kljub naši predpostavki, da bo to pomemben del spremljanja bogoslužij/obredov, nasploh ne pritegne, saj je to neustaljena oblika in vsebina, ki je marsikdaj tudi izredno zahtevna. Pomislimo že na to, da mnogi ne razumejo izvirnega jezika in so odvisni od tolmača, ki z zamikom sledi izvirnemu govorcu (Maček 2018, 117-125; Žigon 2017, 153-171).

Zadnja pomembna ugotovitev je, da so verniki po zaprtju cerkva pogrešali predvsem ,občestvenost' in skupnost, ki jo omogoča cerkev kot stavba. Povezanost ob bogoslužju prek e-medijev jim tako ni dala občutka, kakor jim ga ponuja povezanost v prostoru, to je: v cerkvi. Ker smo anketirali člane cerkvenega pevskega zbora, je bila naša predpostavka, da bodo pogrešali predvsem glasbo, vendar pa se je izkazalo, je bila glasba resda visoko na lestvici pomembnosti, ni pa bila prva; prednjo so respondenti umestili ,občestvenost'. Tudi to je pomembno sporočilo za odločevalce v SŠK in v Cerkvi na Slovenskem.

Na koncu velja poudariti, da imata ta raziskava in analiza številne omejitve, zato ju ne moremo posplošiti in prenesti na celotno stanje v državi. Prva omejitev je, da ukrepi v Cerkvi na Slovenskem zoper COVID-19 še niso končani, zato njihovega učinka še ne moremo dokončno izmeriti. Druga omejitev je majhnost in omejenost vzorca respondentov, ki so na anketo odgovarjali. Tretja omejitev sta rudimentarnost in nezadovoljiva razčlenjenost ankete, to pa onemogoča širše in bolj poglobljene odgovore in posploševanje rezultatov.

Kljub vsem omejitvam je analiza pokazatelj nekaterih trendov in razmišljanj, ki bi jih veljalo bolj raziskati, morda tudi s serijo poglobljenih polstrukturiranih intervjujev, s fokusnimi skupinami in/ali anketo. To bi na postavljena vprašanja dalo bolj natančne, predvsem pa bolj strukturirane odgovore.

\section{Kratica}

SŠK - Slovenska škofovska konferenca. 


\section{Reference}

Bahovec, Igor. 2015. Christianity in confrontation with individualism and crisis of Western culture: person, community, dialog, reflexivity, and relationship ethics. Bogoslovni vestnik 75, št. 2:335-346.

Boezi-Gio, Francesco. 2000. „Ecco perché le chiese non dovevano essere chiuse." [pogovor s profesorjem Robertom De Matteiom, predsednikom fondacije Lepanto]. IIGiornale.it, 5. 3. https://www.ilgiornale.it/news/cronache/ ecco-perch-chiese-non-dovevano-essere-chiuse-1834988.html (pridobljeno 28. 4. 2020).

Congregatio de cultu divino et disciplina sacramentorum. 2020a. Decreto: In tempo di COVID-19. Prot. n. 153/20. Sveti sedež, 19. 3. http://www.cultodivino.va/content/cultodivino/it/documenti/decreti-generali/decreti-generali/2020/decreto-triduo-pasquale-2020. html (pridobljeno 13. 5. 2020).

- - . 2020b. Decreto: In tempo di COVID-19 (II). Prot. n. 154/20. Sveti sedež, 25. 3. http://www. cultodivino.va/content/cultodivino/it/documenti/decreti-generali/decreti-generali/2020/ decreto-triduo-pasquale-2020--ii-.html (pridobljeno 13. maja 2020).

- - . 2020c. Preghiera Universale Venerdì Santo 2020. Adnexus decreto. Prot. n. 155/20. Sveti sedež, 30. 3. http://www.cultodivino.va/content/cultodivino/it/documenti/decreti-generali/decreti-generali/2020/preghiera-universale-venerdi-santo-2020/adnexus.html (pridobljeno 13. 5. 2020).

- - - 2020d. Decretum de Missa in tempore universalis contagii. Prot. N. 156/20. Sveti sedež, 30. 3. http://www.cultodivino.va/content/cultodivino/it/documenti/decreti-generali/decreti-generali/2020/messa-in-tempo-di-pandemia/decretum.html (pridobljeno 13. maja 2020).

Congregazione per le Chiese Orientali. 2020. Comunicato della Congregazione per le Chiese Orientali: Colletta per la Terra Santa 2020. Sveti sedež, 2. 4. https://press.vatican.va/ content/salastampa/it/bollettino/pubblico/2020/04/02/0197/00449.html (pridobljeno 24. 3. 2020).

Diocesi di Roma. 2020a. Decreto del cardinale vicario Angelo De Donatis dell'8 marzo 2020. Diocesi di Roma, 9. 3. http://www.diocesidiroma.it/decreto-del-cardinale-vicario-angelo-de-donatis-dell8-marzo-2020/ (pridobljeno 3. 5. 2020).

- - . 2020b. Decreto del cardinale vicario Angelo De Donatis del 12 marzo 2020. Diocesi di Roma, 12. 3. http://www.diocesidiroma.it/decreto-del-cardinale-vicario-angelo-de-donatis-del-12-marzo-2020/ (pridobljeno 3. maja 2020).
Direttore della Sala Stampa della Santa Sede. 2020c. Dichiarazione del Direttore della Sala Stampa della Santa Sede. Sveti sedež, 29. 4. https://press.vatican.va/content/salastampa/ it/bollettino/pubblico/2020/04/29/0252/00555.html (pridobljeno 5. 5. 2020).

Filej, Bojana, in Boris Miha Kaučič. 2019. Vpliv duhovnosti na kakovost življenja starejših v domačem in v institucionalnem okolju. Bogoslovni vestnik 79, št. 2:555-568. https://doi. org/10.34291/bv2019/02/filej

Freytag, Gustav. 2003. Der Dreißigjährige Krieg 1618-1648: Die Dörfer und ihre Geistlichen; Der Frieden. Bad Langensalza: Verlag Rockstuhl.

Globokar, Roman. 2020. COVID-19, nacionalna država in družbeni nauk Cerkve. Bogoslovni vestnik 80, št. 2:379-394. https://doi. org/10.34291/bv2020/02/globokar

Katekizem katoliške Cerkve. 1993. Prevedel Anton Štrukelj. Ljubljana: Družina.

Keber, Katarina. 2018: Španska gripa leta 1918 v osrednjeslovenskem prostoru. V: Mojca Smolej, ur. 1918 v slovenskem jeziku, literaturi in kulturi: 54. seminar slovenskega jezika, literature in kulture, 71-77. Ljubljana: Filozofska fakulteta, Oddelek za slovenistiko, Center za slovenščino kot drugi in tuji jezik.

Kočevar, Vanja, in Miha Preinfalk. 2018. Tridesetletna vojna in slovenski etnični prostor v prvi polovici 17. stoletja: znanstveni posvet, program in povzetki referatov. Ljubljana: ZRC SAZU, Zgodovinski inštitut Milka Kosa.

Kraner, David. 2018. Vpliv socialnih reprezentacij o katoliški Cerkvi v Sloveniji na družbene napetosti. Bogoslovni vestnik 78, št. 2:611-624.

- - - 2020a. Elektronsko sporočilo avtorju z dne 27. 4. 2020. Osebni arhiv avtorjev članka.

- - - 2020b. Elektronsko sporočilo avtorju z dne 5. 5. 2020. Osebni arhiv avtorjev članka.

Macuh, Bojan, in Andrej Raspor. 2018. Duhovna oskrba starejših v domovih za starejše. Bogoslovni vestnik 78, št. 2:641-660.

Maček, Amalija. 2019. Literaturübersetzer als Dolmetscher, Moderatoren oder sogar Autoren. Acta Neophilologica 52, št. 1/2:117-125.

Mihelič, Rok. 2015. Posebej o pravnem statusu katoliške Cerkve. Bogoslovni vestnik 75, št. 1:129-142.

Naglič, Andrej. 2013. Verska dejavnost med državnim pravom in avtonomno ureditvijo Cerkva in drugih verskih skupnosti. Bogoslovni vestnik 73, št. 1:85-96. 
Penitenzieria Apostolica. 2020. Decreto della Penitenzieria Apostolica circa la concessione di speciali Indulgenze ai fedeli nell'attuale situazione di pandemia. Sveti sedež, 20. 3. https:// press.vatican.va/content/salastampa/it/bollettino/pubblico/2020/03/20/0170/00378.html (pridobljeno 3. 5. 2020).

Petkovšek, Robert. 2020. »O pravi razdalji«: pogled $\mathrm{z}$ vidika mimetične teorije. Bogoslovni vestnik 80 , št. 2:293-320. https://doi. org/10.34291/bv2020/03/petkovsek

RaiNews. 2020. Dopo monito di Papa Francesco, la Diocesi di Roma ci ripensa e riapre tutte le chiese. Rai: Radiotelevisione Italiana, 13. 3. http://www.rainews.it/dl/rainews/articoli/ La-Diocesi-di-Roma-chiude-tutte-le-chiese-Papa-misure-drastiche-non-sempre-buone-d4f3064e-c8db-44c5-a6dd-a7bb6dbdf844. html (pridobljeno 6. 5. 2020).

Roter, Zdenko. 1996. Država in cerkev - kako naprej? Teorija in praksa 33, št. 1:73-85.

Slatinek, Stanislav. 2020. Pastoralno-liturgična navodila slovenskih škofov v času razglasitve epidemije nalezljive bolezni SARSCoV-2 in neposredno po njem. Bogoslovni vestnik 80 , št. 2:403-413. https://doi.org/10.34291/ bv2020/02/slatinek

Slovenska katoliška Cerkev. 2014. Nauk cerkve o odpustkih. Katoliška Cerkev, 1. 11. https:// katoliska-cerkev.si/nauk-cerkve-o-odpustkih (pridobljeno 7. 5. 2020).

- - - 2020. Najpogostejša vprašanja in odgovori za katoličane ob vzpostavitvi javnega bogoslužja v slovenskih cerkvah med epidemije COVID-19. Katoliška Cerkev, 4. 5. https://katoliska-cerkev.si/najpogostejsa-vprasanja-in-odgovori-za-katolicane-ob-vzpostavitvi-javnega-bogosluzja-v-slovenskih-cerkvah-v-casu-epidemije-covid-19 (pridobljeno 13. 5. 2020).

Slovenska škofovska konferenca. 2020a. Izredna navodila slovenskih škofov za preprečevanje širjenja koronavirusa COVID-19: odpoved svetih maš do preklica. Št. 76-7/2020. Katoliška Cerkev, 13. 3. https://katoliska-cerkev.si/ izredna-navodila-slovenskih-skofov-za-preprecevanje-sirjenja-koronavirusa-covid-19-odpoved-svetih-mas-do-preklica (pridobljeno 30. 4. 2020).

- - - 2020b. Navodila slovenskih škofov za vzpostavitev javnega bogoslužja v slovenskih cerkvah med epidemije COVID-19, št. 119/20. Katoliška Cerkev, 30. 4. https://katoliska-cerkev.si/media/datoteke/2020/200430-Navodila\%20za\%20uvajanje\%20bogosluzja\%20po\%20 epidemiji.pdf (pridobljeno 5. 5. 2020).

- - . 2020c. Vprašanja in odgovori ob vzpostavitvi javnega bogoslužja v slovenskih cerkvah v času epidemije COVID-19. Katoliška Cerkev, 11. 5. https://katoliska-cerkev.si/najpogostejsa-vprasanja-in-odgovori-za-katolicane-ob-vzpostavitvi-javnega-bogosluzja-v-slovenskih-cerkvah-v-casu-epidemije-covid-19 (pridobljeno 12. 5. 2020).

Slovenska tiskovna agencija. 2020. Podatki o okuženih s COVID19. STA, 4. 5. http://www.sta. si (pridobljeno 10. 5. 2020).

Strehovec, Tadej. 2020. Institucionalna religijska rezilientnost $\mathrm{v}$ času pandemije koronavirusa $\mathrm{v}$ Sloveniji. Bogoslovni vestnik 80, št. 2:395-401. https://doi.org/10.34291/bv2020/02/strehovec

Svetlič, Rok. 2016. Religija kot ,le podlaga' države. Bogoslovni vestnik 76, št. 1:37-49.

Udovič, Boštjan. 2020. ,Mass for the homeland': (just) a religious ceremony or a religious, diplomatic and statehood-strengthening activity? Bogoslovni vestnik 80, št. 1:145-159. https:// doi.org/10.34291/bv2020/01/udovic

UTILS. 2020. Analisi dettagliata giornaliera dei casi positivi totali registrati (Stanje obolelih s COVID19 v Italiji). II Messaggero, 11. 3. https:// www.ilmessaggero.it/dati_coronavirus/ (pridobljeno 5. 5. 2020).

Valentan, Sebastijan. 2020. Primerjalnopravni vidik omejitve verske svobode in aktualnost primerov med pandemijo COVID-19. Bogoslovni vestnik 80, št. 2:609-622. https://doi. org/10.34291/bv2020/013/valentan

Vatican News. 2020. Epidemie, quarantene, chiese vuote: precedenti della storia. Vatican news, 9. 4. https://www.vaticannews.va/it/vaticano/ news/2020-04/epidemie-quarantene-chiese-vuote-precedenti-storia-tornielli.html (pridobljeno 4. 5. 2020).

Völker, Karl-Hermann. 2011. Schlachtfeld und Lazarett. Hessische Niedersächsische Allgemeine, 25. 2. https://www.hna.de/lokales/frankenberg/schlachtfeld-lazarett-1139336.html (pridobljeno 4. 5. 2020).

Zakonik cerkvenega prava. 2006. Ljubljana: Družina.

Zupanič Slavec, Zvonka, diskutant. 2019. Intervju: Epidemije skozi čas ob pandemiji novega korona virusa 2019. Ljubljana: RTV SLO, oddaja Intervju, 1. 4. https://4d.rtvslo.si/arhiv/intervju-tv/174681930 (pridobljeno 28. 4. 2020).

Žigon, Tanja. 2017. Übersetzung oder Adaption: Fallbeispiel Jakob Alešovec (1842-1901). Acta neophilologica 50, št.1/2:153-171.

Žužek, Aleš. 2020. Obdobja v zgodovini, ko niso obhajali svetih maš. Aleteia, 22. 3. https:// si.aleteia.org/2020/03/22/obdobja-v-zgodovini-ko-niso-obhajali-svetih-mas/ (pridobljeno 30. 4. 2020). 